\title{
The Impact of RMB International on Pricing Power of China's Bulk Stock
}

\author{
Ting Wang \\ School of Economics, Jinan University, Guangzhou, China \\ Email: realhd@163.com
}

How to cite this paper: Wang, T. (2018). The Impact of RMB International on Pricing Power of China's Bulk Stock. Journal of Financial Risk Management, 7, 139-147. https://doi.org/10.4236/jfrm.2018.71009

Received: February 29, 2018

Accepted: March 27, 2018

Published: March 30, 2018

Copyright (C) 2018 by author and Scientific Research Publishing Inc. This work is licensed under the Creative Commons Attribution International License (CC BY 4.0).

http://creativecommons.org/licenses/by/4.0/

\begin{abstract}
With the development of our economy, China has an increasingly demand for bulk commodities and becomes a net importer of many bulk commodities. However, China has little control over bulk commodity pricing and has to passively accept the prices, which damages the interest of our country badly. Adding the RMB to the SDR is the new start of internationalization of RMB, and brings the new opportunity for controlling over bulk commodity pricing. Based on a large number of the existing literature, this paper first takes point of view in the opportunities and challenges of the join of RMB to the SDR, then analyzes the mechanism of the bulk commodity and the situation of lack of bulk commodity pricing. Finally, this paper summarizes the internationalization strategy of RMB under the background of commodity pricing power and the influence of RMB entry into SDR on the pricing power of commodities in China.
\end{abstract}

\section{Keywords}

RMB Internationalization, Bulk Stock, Pricing

\section{Introduction}

On December 1, Bejing time at 1, the International Monetary Fund (IMF) formally announced RMB into Special Drawing Rights (SDR) basket; the new SDR basket will take effect on October 1, 2016. In the future, RMB will be the fifth international reserve currency in addition to dollar, euro, yen and pound and the proportion is up to $10.92 \%$. RMB accession to the SDR basket is of strategic significance for China's economy and world economic development. The internationalization of RMB is making the yuan a world currency and must enlarge foreign circulation of RMB. There are three standards: First is the overseas circulation; second is the financial products denominated by RMB that become main 
investment tool of international financial institutions; third is the proportion of $\mathrm{RMB}$ for payment in international trade. At present, the currency in the SDR currency basket has a relatively greater influence on the international market. After the RMB is added to the SDR, it will play a very important role in the whole international market, just like other internal currencies. Joining the SDR fundamentally represents that the world economy and society are beginning to recognize the growing economic influence of China and to enhance confidence in the RMB in the international market. The SDR currency is generally regarded as a safe haven currency (safe haven currency is also called hedge currencies, which is not susceptible to political, war, market fluctuations and other factors that can best avoid these risks. It is a relatively stable currency that is not easily depreciated.), a status that the private and the public sector within the international community are beginning to increase its use of the RMB.

According to relevant statistics from China's customs, as of 2013, industrial raw materials, agricultural products, chemicals and many other important commodities in international trade have become the world's most important importer, and the degree of dependence on foreign trade is rising year by year. Buy low and sell high has become Chinese economic pain; the product profit is very low, and most of the profits are exploited by foreign manufacturers. By contrast, prices of raw material and resources fell year after year on the basis of China's main export products; low price competition in export trade becomes more and more fierce. As the representative of rare earth, coke, silk, and Chinese medicine, while the export scale has increased, the unit price of exports has continued to decline. In the visible future, China's demand for commodities, especially resource products, will continue to increase, while fluctuations in commodity prices affect China's economic development. On the macro level, commodities are in the upper position in the entire economic chain, and rising prices will lead to raw material pull inflation, triggering livelihood problems, and pose a threat to the country's political and economic security. On the micro level, high buy and sell low greatly compressed the profit margins of enterprises, leading to enterprises have to lower $\mathrm{R} \& \mathrm{D}$ costs, delay the pace of industrial upgrading, and reduce the overall competitiveness of related industries. Not only endanger the sustainable development of the industry, but also bring adverse effects to the macro industrial layout of our country. In such a background, research how to strive for the international commodity pricing, is of great significance to the development of related industries and survival.

The internationalization of the RMB and fighting for international commodity pricing has a complementary relationship. For example, on the one hand, our objective is to hold dollars through our exchange for the commodity. It can be seen that the pricing of commodities is very important for the dollar to achieve a world standard currency. We can say that it is the dollar standard now. On the other hand, we think that the commodity is now the world standard currency, and the reason why the dollar can become the world standard currency is the 
essential reason for the commodity pricing right behind the US dollar. On the road of internationalization of the RMB, striving for commodity pricing is a major project, and how to use the existing RMB internationalization opportunities, a good platform after the entrance of SDR, strengthen the RMB in the international capital market position, seek benefits in international trade, strive for a certain commodity pricing right is the focus of this paper.

Ahmet E, Kocagil (2004) studied the daily convenience earnings performance of six commodity markets. Baillie R T, Booth G G, Tse Y, and Zabotina T (2002) compares Price discovery and common Factor models for the price discovery function of different markets. Nick Ronalds, Wang Xueqin (2006) pointed that the preparatory work of stock index futures has been gradually improved, and the timing of the introduction of the stock market has matured. In the coming year, this innovative product is expected to become an important label in China's financial market. Ronalds, Wang Xueqin (2007) said, For a long time, China has been the world s largest commodity producer, consumer and importer, but the number of the advantage is difficult to translate into a price advantage. How to fully develop the domestic futures market, form "the Chinese price" is to enhance the China in key global commodities domain influence step. Rentzler Joel, Tandon Kishore, Yu Susana (2006) researched the Short-term market efficiency in the futuresmarkets and commodity market. The topic of RMB internationalization has been widely studied, But few people have studied the impact of commodity prices on the pricing of commodities from the perspective of the internationalization of the RMB.

\section{The Opportunity and Challenge of RMB's Entry into SDR}

\subsection{Opportunities}

The RMB was included in the "basket of currencies" (Basket of currencies refers to a combination of exchange rate of foreign currency as the set of reference, a foreign currency account for the proportion of the portfolio benchmark for the importance of foreign currency is usually in the country in international trade, is a set of currency currencies according to certain proportion of.) is an important milepost of RMB internationalization, reflects China globalization efforts and irreversible, is of great significance to the promotion of the international monetary system reform, Adding the RMB to SDR will make the realization of international development, and constantly improve the international status of RMB, ensure its transformation into a true international currency; and the renminbi is added to the SDR for the present stage of cross-border trade settlement, investment has irreplaceable function. China's iron ore, oil and a series of international commodity pricing above has more sufficient right to speak. It can reduce the cost of borrowing abroad in our country, to ensure the Chinese company achieved overseas expansion, rising global demand for real Renminbi. Finally, the currency basket will form a mechanism of force, force a reform of finance, Chinese financial system will be able to get more and more open. 


\subsection{Challenges}

RMB is added to the SDR also brings certain risks and challenges, therefore we must toanalysis rationally and think seriously. From the perspective of economic development, Chinese financial system is not mature enough, did not reach the United States and other developed countries with more advanced level, lack of regulatory capacity and channels to avoid the risk, and the two-way capital volatility will make liquidity management of central bank has more challenges. Moreover, the RMB accession to the SDR also indicates that the RMB needs to bear more external pressure, and we should be able to maintain the relative stability of the ratio, the continued appreciation of the space. From a political point of view, the RMB was incorporated into the SDR, marking the beginning of sharpening relations between China and the United states. SDR is a super sovereign currency, marks the dollar will lose its unique position in the world's main reserve currency.

\section{Strategy under the Commodity Pricing Power}

\subsection{Pricing Mechanisms for Commodities}

The international pricing power of commodities means that in the international trade of commodities, whether a country has the ability to influence the price of the trading target and how much can affect the final transaction price of the subject of the transaction. Broadly speaking, the ability of international pricing refers to the impact of commodity prices in the international market, includes three aspects: one is the ability to influence the contract price of specific international trade contract negotiations; two is the ability to influence international benchmark prices in the international pricing under the framework of the existing rules; the three is to develop the ability to modify the current international pricing rules. In reality, the United States has mastered the pricing power of most commodities, because the American commodity futures market developed earlier, and now has formed a complete international futures market. The pricing mechanism of commodities is to determine the price patterns of commodity import and export trade, including the generally accepted pricing rules and reference benchmark prices by both buyers.

Through the international commodities futures market pricing has gradually formed different types of commodities and futures market based pricing. The basic metals such as copper, aluminum, lead, zinc, tin, nickel prices mainly by the London Metal Exchange (LME). The soybean, corn, wheat and other agricultural products prices in Chicago commodity exchange (СВОT) as the benchmark price. Crude oil and other energy prices depends mainly on the New York Mercantile Exchange (NYMEX) and so on. Futures trading helps to find commodity prices, but it also exacerbates commodity price volatility. The futures market is active and has the function of price discovery, which is beneficial to increase market transparency, improve the efficiency of resource allocation and transaction efficiency. However, due to the increasing financial nature of futures 
trading, the speculative factors of international commodity prices are becoming more active, which has aggravated the fluctuation of international commodity prices.

\subsection{The Absence of Pricing Power of Bulk Commodities in China}

"China's pricing system in the international trading system has almost collapsed," commerce ministry spokesman Yao Jian said bluntly in 2010. "A major problem facing China today is the absence of pricing power for commodities." Our country is an important participant in the global market, and even become the world's first buyers in some commodities. We have a lot of goods is a rigid demand, rather than the influence of demand is much smaller. Because of the rigid demand, we can only in a small range of the price on the price, and do not have pricing power. Not only we lack of commercial strength, but also the lack of financial development. Our enterprises can only fight alone.

\subsection{Reasons for the Lack of Pricing Power of Bulk Commodity}

Lack of consideration of commodity pricing. For example, China is the world's largest reserves of rare earth, the largest export country, rare earth industrial reserves of $36 \%$ of the world, production accounted for $97 \%$ of the world. Rare earth products are important strategic resources in high technology and international competition. Their reserves are relatively concentrated, and have the advantages of natural monopoly. However, the tendency of China's policies to earn foreign exchange and attract foreign investment, the management of export quotas is very loose, leading to the excessive exploitation of rare earth resources, excessive export of rare earth, disorderly competition, and lower prices.

Monopoly control. In the case of soybean, the current soybean international trade mainly for four grain $\mathrm{ABCD}$ ( $\mathrm{ABCD}$, the A A (Archer Daniels Midl) B Bangee (Bunge), C (Cargill) D, Cargill, Louis Dreyfus (Louis Dreyfus) control). For the sake of pricing control strategy and the pursuit of excess profits, several dealers strategic implementation of the whole industry chain covering upstream to downstream to soybean production and enterprise. Through mergers and acquisitions, equity participation, allocation of funds, providing agricultural loans and other means to cover upstream production links, buyout sales rights to the downstream, now the $90 \%$ South American soybean grain control in these big hands. Because of the large dependence on the foreign trade of soybean, the enterprises in our country lose seriously if they don't buy the corresponding soybean.

Immature financial derivatives. Compared with the developed countries in Europe and America, China began to open the financial derivatives market from 1990. It was marked by the establishment of the Zhengzhou grain wholesale market. At the beginning of China's opening of the financial derivatives market, the futures contracts based on floor trading were the main ones, while our country lacked a healthy and transparent market environment, Not only did not play a role in price discovery and risk avoidance, but exacerbated by financial risks. 
Speculation by international hedge funds. The international fund-Red kites, Goldman Sachs and JP Morgan investment bank conspiracy to purchase a large number of LME warehouse inventory, spot market caused by the scarcity of resources, and carried high premium, the price of LME cash in July and March showed back structure. After selling up the spot, the fund buys the futures contract in the long term, and then when the contract expires, the futures will be converted into stock. Such repeated operations, and constantly raise savings by raising the profits, our enterprises in the import of copper concentrate and cathode copper had to pay higher costs.

\section{The Influence of RMB's Entry into SDR on the Pricing Power of Bulk Commodities}

Over the past ten years, the internationalization of the RMB development process is the primary feature of policy driven, are external pressure forced results. For example, the reform of exchange rate formation mechanism was initiated in 2005. From the yuan intends to join the SDR, China government began to foster the offshore renminbi market. Mainland financial institutions started RMB bond market in Hongkong in 2009; The central government implemented Renminbi qualified foreign institutional investors (RQFII); Recently, The Belt and Road will continue to expand the use of the renminbi in cross-border lending and cross-border securities trading.

\subsection{The Exchange Rate Risk}

With the internationalization of $\mathrm{RMB}$, it will reduce the risk of exchange rate and promote the development of China's international trade and investment. In particular, the cross-border flow of RMB cash in the real economy, such as border trade, has eased the shortage of means of settlement in bilateral exchanges to some extent, and promoted and expanded bilateral economic and trade exchanges. In this process, "the introduction of transitional link" to "go out" to let the market transaction mode is gradually recognition at home and abroad, a large number of foreign customers through cross-border settlement can be directly involved in the domestic commodity trading market.

\subsection{Transactional Model}

At this stage, the unique domestic resources of the commodity trading market are traded in the market. The international trade mode, risk control, transaction settlement and other aspects will be more standardized, more international recognition. The unique products China through market circulation directly to foreign countries, not only conducive to the rapid consumption of excess capacity Chinese, there is conducive to the formation of Chinese special resources right.

\subsection{Assets Valuation}

In the early expansion of the rectification, the domestic commodity trading 
market gradually on the right track. In the trend of internationalization of the $\mathrm{RMB}$, the domestic commodity trading market can not only be based on the domestic, but also international development vision. In the settlement of funds, after the internationalization of the RMB, foreign trade and investment can be denominated and settled in domestic currency, which greatly reduces the exchange rate risk and promotes international trade. Commodity trading market should be clear direction of development, in compliance with the premise of development, with the internationalization of the RMB, and gradually toward the international.

\section{Strategic Suggestions for China's International Commodity Pricing Rights in the New Era}

\subsection{Accelerating the Pace of Internationalization of RMB}

Throughout history, why the developed countries' futures exchange can become the pricing center of some commodities in the world, there are many reasons, but it is undeniable that the futures settlement currency plays a very important role. For example, CME, СВOT, and LME all use the US dollar, the world currency as the settlement currency. Our country wants to obtain the international pricing rights of commodities, whether the RMB is stable, whether it has been accepted and approved by other countries and whether it is convenient to use in international settlement plays a crucial role. Because of the country's control over the exchange rate, the RMB can not be freely convertible, which greatly hinders the internationalization of RMB. President Xi took office, and accelerated the process of internationalization of the $\mathrm{RMB}$, the internationalization of the RMB positioning national strategy, and adopted corresponding measures 。 Such as expanding the fluctuation of RMB, from $1 \%$ to $2 \%$, and plans to liberalize exchange rate control gradually, at the same time, signed currency swap agreements with Russia and ASEAN countries.

\subsection{Working with Foreign Commodity Enterprises to Complete the Technology and Capital Output}

China is a global industrial country, although it is still in the stage of industrialization, and still have considerable technological advantages relative to many raw materials supply countries. After thirty years of economic development, our country has a certain amount of economic reserves. Although it has not yet completed its transformation from an industrialized country into a capital country, the accumulation of capital in the early stage is of considerable help to the present stage, These early accumulation of capital can not just let it idle, but for our country's next step of strategic deployment, with the accumulation of capital into an international physical assets. Exporting our technology and capital to countries and regions in need, and the areas currently in line with our output conditions are the targets we should focus on. These areas must have a stable political system, rich resources, and the lack of adequate funds and technology. 


\subsection{Improving China's Financial System and Establishing Mature Financial Markets}

The commodity market is mainly for pricing of futures contracts, such as the CBOT soybean futures contracts, LME futures contract. Futures markets are becoming more and more widespread, and brokerage firms around the world are helping to promote futures business. In such a background, the pricing function of futures market has attracted more and more attention, the domestic futures market from the domestic pricing center become the international pricing center has become the inevitable choice of production and consumption of power.

\subsection{Bidding for Overseas Resources to Break the Oligopoly}

International oligarchs control resources and information, and consider the impact of maximizing the profits of an enterprise through its monopolistic advantage. In order to get the right to speak in the international commercial unit pricing, China must resolutely carry out the "going out" strategy, obtain overseas resources and break the pattern of Oligopoly. Japan is a good example of this. In twentieth Century 50s and 60s, Japan related enterprises began to layout upstream resources, and actively participate in investment and development of iron ore. After 2002-2008 of the economic cycle, China is also aware of the importance of controlling overseas commodity resources and began a series of mergers and acquisitions overseas.

\subsection{Eliminate Backward Production Capacity and Increase Industry Concentration}

In order to improve the bargaining power of our country, industry integration must be carried out to improve industry concentration and eliminate backward production capacity. On the one hand, we should formulate corresponding backward production capacity elimination plans and environmental protection plans through administrative means, and eliminate the enterprises with low efficiency, high pollution and high energy consumption gradually. On the other hand, we should speed up the domestic market reform, encourage mergers and acquisitions, and integrate upstream and downstream industrial chain. Through the elimination of backward production capacity, improve industry concentration, and avoid long outside, is conducive to our centralized control of resources in the negotiations with foreign countries. At the same time, after mergers and acquisitions, enterprises can scale into effect, effectively reduce the cost of enterprises, and improve the competitiveness of enterprises.

\subsection{Setting up a Perfect Commodity Information Service System}

On the one hand, the government departments should co-ordinate the planning, the preparation of various information index for domestic enterprises and investors as a reference, such as the United States' non farm employment index, consumer confidence index, durable goods orders index. The government should give full play to the advantages of data statistics and thoroughly under- 
stand the real data of various industries and publish them in a timely manner, such as domestic cotton planting area, weather conditions, the national blast furnace operation rate, the utilization capacity of electrolytic aluminum and so on. On the other hand, we should improve our commodity price warning mechanism as soon as possible. As the leading trade association, with the support of the government and enterprise cooperation, in-depth analysis of relevant factors affecting commodity prices, timely publication of the corresponding data and information to the community, to avoid playing the business risk and crisis.

\section{Conclusion}

The commodity trading market will experience "introduction" and "go out" changes, including trading patterns, market participants, market dealers, varieties, commodity pricing rights and other aspects of qualitative changes. The trading model of commodity trading market is also in the stage of exploration and innovation, and it also needs to draw on the successful experience of international commodity trading market. In fact, the process of internationalization of RMB and the pricing power of commodities affect each other.

\section{References}

Baillie, R., T., Booth, G. G., Tse, Y., \& Zabotina, T. (2002). Price Discovery and Common Factormodels. Journal of Financial Markets, 5, 309-321. https://doi.org/10.1016/S1386-4181(02)00027-7

Joel, R., Kishore, T., \& Susana, Y. (2006). Short-Term Market Efficiency in the Futures Markets: TOPIX Futures and 0-Year JGB Futures. Globa Finance Journal, No. 16, 330-353.

Kocagil, A. E. (2004). Optionality and Daily Dynamics of Convenience Yield Behavior: Anempirical Analysis. The Journal of Financial Research, XXVII, 143-158. https://doi.org/10.1111/j.1475-6803.2004.00082.x

Ronalds, N., \& Wang, X. Q. (2006). The Dawning of Financial Futures in China (pp. 27-43). Futures Industry.

Ronalds, N., \& Wang, X. Q. (2007). History, Development and Prospects Intelligent Commodity Investing (pp. 58-147). Chinese Commodity Markets. 